\title{
THE SYSTEM OF THE MANAGEMENT OF STABLE DEVELOPMENT OF RURAL TERRITORIES: COMPARISON OF THE NATIVE AND FOREIGN EXPERIENCE
}

\author{
Irina Lutsenko \\ Postgraduate Student \\ Department of Audit and Economic Analysis \\ University of the State Fiscal Service of Ukraine \\ 31 Universitetska str., Irpin, Ukraine, 08200 \\ lutsenko_iryna@ukr.net
}

\begin{abstract}
The article elucidates the problems and tendencies of formation of the native system of the management of the stable development of rural territories in the context of budgetary policy and general European experience.

The author has systematized the types of state support of the stable development of the rural territories by the forms of budgetary regulation and their legislative support. The world experience of the state support of budgetary regulation of the development of rural territories and the features of the influence of state subventions on the economic safety of local territories were studied. The main problems and tendencies of the management of the stable development of rural territories were analyzed and the weak places - dependence of rural economy on agrarian production, decrease of effectiveness of existent resources usage and worsening of social-productive and ecological infrastructure of the villages were determined.

Alongside with it the inconsistency of the level of development of Ukrainian agrarian sector and rural territories in general to the world level and the standards of EU countries was revealed that is for today the significant obstacle on Ukraine's way the to the membership in European Union. It can be explained especially by the general policy of development of the rural territories in European Union that is realized within the Common Agrarian Policy (CAP). Thus, on the way to the finish of administrative-territorial reform and decentralization of the power authorities Ukraine must take into account the priorities of CAP of EU countries as the target orientation points for the formation of the system of the management of stable development that would provide the balance of agricultural and rural development.

Taking into account the experience of development of EU agrarian policy, based on the domination of the development of rural territories over the other tasks, Ukraine must adapt its policy to the European standards and to follow the course of changes of agricultural development of EU countries for the timely modernization of the forms of state support of the stable development of rural territories.
\end{abstract}

Keywords: management of the stable system of rural territories, regulation, decentralization, budgetary system, state support, European integration.

\section{Introduction}

The notion "management of the stable development of rural territories" is not new by its essence for the native science. Already in the first half of XX century the famous Ukrainian academician V. Vernadsky has formulated the conception of the further synchronous harmonic development of society in three directions: economic, environmental and social. He called his doctrine "noosphere" (sphere of mind), which essence was in the reasonable management from one generation to the other: the quality and safety of the human life must not decrease; the state of environment must not worsen; social progress must take place. So, if biosphere is a cover of earth together with natural resources and all living organisms that can accumulate the solar energy, compensating the own consumption, it evolves at the human rational activity into the qualitatively new level - noosphere that provides that the human mind it is a center of Universe. The theory of noosphere that was offered by V. Vernadsky in Sorbonne (1922-1923) it is a first step in the creation of the modern conception of stable development.

As it is stated in the work [1] «...the world and native experience testify that the stable development of rural territories is the one of main factors of stabilization of the socioeconomic relations, creation of conditions for the stable economic growth of the state. That is why the main components of the state policy on the support of rural development in Ukraine are the complex of legal, orga- 
nizational and economic arrangements, directed on the raise of effectiveness of the functioning of agrarian economic sector, solution of socio-ecological problems of the rural population and the support of impetuous stable development of the rural territories.

In several countries the state support of the system of the management of stable development of the rural territories is a component of local self-government and is a totality of different instruments and key factors, the one of which is financial mechanism and budget that is an efficient key factor, especially for the central power bodies, using which they stimulate the development of socio-economic processes on the separate territories and in the country as a whole. But the task of effective usage of state budget, as a key factor of the influence on socioeconomic processes, remains unsolved in Ukraine till know.

\section{Analysis of the literary data and statement of the problem}

The solution of the problem of state support of the development of rural territories is realized in scientific works of many scientists and practicians, concentrated in scientific environments that deal with the study of the different aspects of the management of the stable development of national economy, namely: Institute of economy of the management of nature and stable development, NAS of Ukraine, Institute of economy and prognostication, NAS of Ukraine, NEC "Institute of agrarian economy", NAAS of Ukraine, Institute of demography and social studies, named after M. V. Ptukha, NAS of Ukraine and others. Detailing the contribution of aforesaid centers in the formation of the modern theory of stable development of Ukrainian national economy, let's accent the importance of the following studies of this problem. Especially in the works [2] and [3] the essence of innovative development of economy of the rural territories and their prospects were explained and in the works $[4,5]$ and [6] the problems that decelerate European integration were considered, and in $[1,7,8]$ and [9] the theoretical fundament of the state management of development of rural territories was laid and the environmental aspects were not accented.

All mentioned publications have a common feature - they need the deep analysis of the world experience of the state support of stable development of rural territories at the deficit of free budget costs under modern conditions of transformation of the national economy that is insufficiently studied.

But in these publications the task of budget usage as an instrument of active influence on economic situation at the local and regional levels, simulation of the development of enterprise, involvement of investments in the regional economy, priority development of depressive and problem territories is not solved.

\section{Aim and tasks of research}

The aim of research is in elucidation of problems and tendencies of formation of the native system of the management of stable development of rural territories in the context of budget policy and general European experience.

For attaining the set aim the following tasks were formulated:

- to deepen the theoretical principles of conception of formation of the system of management of the stable development for elucidation of the economic essence of main notions;

- to ground the scientific principles of the system of support of the stable development of rural territories on the base of processing of the prominent economic theories.

\section{Materials and methods of research}

The main methodological base is the methods of economic studies, basic principles, scientific theses and modern achievements of economic theory that allow formulate the scientific results on the base of historical, abstract-logical and formalized methods.

\section{Results of research}

The analysis of conclusions and propositions of Rio+20 conference gives a possibility to state that it is obligatory to take into account the environmental component at the management of the development of city settlements and rural territories. That is why in further at the formation of 
theoretical and methodological bases of the strategy of socioeconomic development of rural territories let's take into account by default the environmental factors and correspondent consequences for environment without special references.

As it was noted in the work [8] "...the fixing a quota for the volumes of agro-production directly supports the level of profitableness of farms, limits the levels of monopolists' market prices by introduction of rigid antimonopoly legislation and so on. In other words, neither in the USA, nor in EU countries or Japan, the market anarchy in such relation is not allowed: the strict economic mechanism that optimizes the effect of market and state regulators functions there".

We agree that between urbanized and rural territories must take place the balance of capital investments in infrastructure, budgetary costs and also the increase of financing of programs of economic development of rural territories [2, 4, 10-12].

In organization of the rural territories development acts the European working group (ARGE), especially financed from the programs of European regional development fund (ERDF), European social fund (ESF), European agricultural guarantees fund (EAGGF), Financial instrumental fund of fishing guaranteeing (FIFG) and so on [2].

The construction of the systems of local self-government of modern states is based on their administrative-territorial order that is the one of most important components of the state organization. The aim of division of the state territory in correspondent administrative-territorial units is a creation of conditions for formation of most effective system of public administration, based on the taking into account of geographic, demographic, economic, social, cultural and other special features of territorial units, realized for the provision of its maximal correspondence to the needs of population. Then, the rational territorial state organization it is a base of formation of effective system of public administration in whole and local self-government in particular.

The study of transformational processes in the European space in XXI century gives grounds to make a conclusion that the effectiveness of state regulation of agricultural development is directly connected with the improvement of administrative-territorial order.

The crisis situation in Ukraine states a question about the facilitation of managerial structure, rationality and more effectiveness of regional management. Taking into account the fact, that such transformations have a system character and touch the questions of functioning of public power bodies of the different territorial levels and the review of the spheres of their subject dependence, the renewal of legislation on the local self-government, local state power bodies and branch legislation, first of all budgetary one, takes place in parallel.

The Cabinet on Ministries of Ukraine by the resolution of 19.09.2007 accepted the State target program of development of Ukrainian village till 2025 that must raise the effectiveness of such Ukrainian laws as:

- "On the priority of social development of the village and agro-industry in the national economy";

- "On the stimulation of agricultural economy for the period 2001-2004";

- "On the state support of agricultural economy of Ukraine";

- "On the main principles of the state agrarian policy for the period till 2015" and other.

But the analysis of own observations and publications of colleagues (see, for example, [13]) confirms the low effectiveness of this program.

Taking into account the systematization of the main Aims of Stable Development at the national level, announced by the President of Ukraine Petro Poroshenko [14] at the UNO summit, when the general conception of the new orientation points of development till 2030 were presented, we consider in the further research the stable development of rural territories as a continuous process, at which any economic activity of the rural territories is directed on satisfaction of growing needs of Ukrainian population under condition of preservation of the resource base of aforesaid territories (or joint communities), co-evolutional development of settlement net, production technologies, external environment and other factors that influence the formation of proper life space for the modern and future generations.

Alongside with it in the research [15] was established exacerbation of problem with the one of main components of stable development - social safety of rural territories. For today the critical 
level of asocial capital that decelerates the management of stable development and intensifies the social stratification that favors the formation of dangerous precariat class, is accumulated within the rural territories. The negative influence of precarization on the main social groups was proved in [16] and [17] on the base of empirical data for the period 1994-2013.

It proves that the problem of the management of stable development is the one of most topical, and the significant attention, paid to the stable development, objectively testifies to the political and scientific topicality of this problem. But the problem of stable development does not disappear with time but, on the contrary, grows and becomes more complicated, because the innovative world needs the new approaches in the study and research of the notion of stable development.

Despite the presence of resources and reserves for the stable development and the program of the state support of village, the negative tendencies in the development of rural territories has been intensified last years: reduction of population, decline of production, deceleration of its intensification, insufficient introduction of innovations, weak diversification of economy, unstable environmental situation, worsening of socio-cultural equipping of the villages.

Thus, the inconsistency of the level of development of Ukrainian agrarian sector and rural territories in general to the world level and European standards is for today the significant obstacle on the way of Ukraine to the membership in European Union.

\section{Discussion of the results of research}

The received results continue the new scientific direction of work in the sphere of formation of theoretical basis for the state management of the stable development of rural territories for the strengthening of national economy under conditions of European integration.

The author's understanding of the solution of the problems that decelerate the stable development and make impossible the adequate management will be useful for the leaders of newly created territorial communities and village headmen that for today have no methodical recommendations for the stable development of rural territories.

\section{Conclusions}

According to the set aim and tasks, the theoretical principles of the modern conception of formation of the system of management of the stable development of rural territories were essentially added. Especially, it was proved, that Ukraine is on the way to the finish of administrative-territorial reform and decentralization of power authorities. It was grounded, that taking into account the favorable geographic, climatic, resource and other preconditions of the development of rural territories, Ukraine is potentially able to become a state with priority development of agrarian economy and one of the main supplier of eco-friendly food products on the world markets.

The analysis of the main problems and tendencies of the management of the stable development of rural territories demonstrated the weak places - dependence of rural economy on agrarian production, reduction of the effectiveness of existing resources usage and worsening of socio-productive and environmental infrastructure of villages, which solution allows intensify the stable development of rural territories.

On the base of processing of the contribution of famous economists there were grounded scientific principles of the system of support of the stable development of rural territories that is expedient to be modernized in the direction of formation of Western European model of the stable rural development in Ukraine that must become the finish of decentralization of budgetary system and local power bodies. They must have not only duties but the real control over the local situation that is impossible without the strong financial base. The policy of support of rural population must be radically changed, because this problem is not properly studied and has not the wide support.

Thus, taking into account the experience of development of EU agrarian policy, based on the domination of the development of rural territories over the other tasks, Ukrainian policy must be adapted the European standards and to follow the course of changes of agricultural development of EU countries for the timely modernization of the forms of state support of the stable development of rural territories. 


\section{References}

[1] Zakon Ukrayiny 2982-IV. (2005). Pro osnovni zasady derzhavnoyi agrarnoyi polityky na period do 2015 roku. Available at: http://zakon4.rada.gov.ua/laws/show/2982-15

[2] Problemy ta perspektyvy rozvytku silskyh terytorij Ukrayiny (na prykladi Karpatskogo regionu) (2011). Lviv: Instytut regionalnyh doslidzhen, 60.

[3] Zalizko, V. D., Martynenkov, V. I. (2016). Sutnist innovacijnogo rozvytku ekonomiky silskyh terytorij. Ekonomika APK, 4, 66-74.

[4] Shaptala, K. O. (2012). Vykorystannya yevropejskogo dosvidu rozvytku silskyh terytorij. Kultura narodov Prychernomorya, 229, 7-9.

[5] Borshhevskyj, V. V. (2012). Rozvytok silskyh terytorij v systemi yevrointegracijnyh priorytetiv Ukrayiny. Lviv: NAN Ukrayiny, 216.

[6] Osnovni priorytety Spilnoyi agrarnoyi polityky (SAP) krayin YeS. Agrarian Markets Development Institute. Available at: http://www.amdi.org.ua/uk/home/amdi-news/21-news/300-the-main-prioritiesof-the-common-agricultural-policy-cap-of-the-eu.html

[7] Ulyanchenko, Yu. (2007). Derzhavne regulyuvannya agrarnogo rynku v krayinax YeS i SShA: dosvid dlya Ukrayiny. Derzhavne budivnycztvo, 7. Available at: http://nbuv.gov.ua/UJRN/DeBu_2007_2 56

[8] Stelmashhuk, A. M. (2000). Derzhavne regulyuvannya ekonomiky. Ternopil: TANG, 315.

[9] Burja. V., Moraru, C., Rusu, O. (2008), Sustainable development of the Romanian rural areas. Annales Universitatis Apulensis Series Oeconomica, 2, 645-650.

[10] Gogol, T. V. (2012). Stanovlennya Spilnoyi agrarnoyi polityky Yevropejskogo Soyuzu ta regulyuvannya rozvytku silskyx terytorij. Derzhavne upravlinnya: teoriya ta praktyka, 1. Available at: http://www. academy.gov.ua/ej/ej15/txts/12GTVRST.pdf

[11] Popova, O. L. (2012). Stalyj rozvytok agrosfery Ukrayiny: polityka i mehanizmy. Kyiv: NAN Ukrayiny, 352.

[12] Gubeni, Yu. (2007). Rozvytok silskyh terytorij: deyaki aspekty yevropejskoyi teoriyi i praktyky. Ekonomika Ukrayiny, 4, 62-70.

[13] Zalizko, V. D., Martynenkov, V. I. (2016). Teoretyko-metodologichni aspekty formuvannya strategiyi rozvytku silskyh terytorij Ukrayiny. Akademichnyj oglyad, 1, 101-110.

[14] Oficijne internet-predstavnycztvo Prezydenta Ukrayiny. Available at: http://www.president.gov.ua/

[15] Zalizko, V. D. (2014). Socialna bezpeka silskyh terytorij: problemy ta perspektyvy. Agrosvit, 11, 21-27.

[16] Shkaratan, O. Y., Karacharovskyj, V. V., Gasyukova, E. N. (2015). Prekaryat: teoryya y empyrycheskyj analyz (na materyalah oprosov v Rossyy, 1994-2013). Socyologycheskye yssledovanyya, 12, 99-110

[17] Mansel, J., Heitmeyer, W. (2010). Precarity, Segregation, and Poverty in the Social Space. Overview of the Research Status. Available at: https://difu.de/publikationen/precarity-segregation-and-poverty-in-the-social-space.html 